\title{
Microbial Conversion of Vegetable Wastes for Bio fertilizer Production
}

\author{
D. Indumathi \\ Department of Zoology, Vellalar College for Women, Erode-12, Tamilnadu
}

\begin{abstract}
Microbial degradation has recently emerged as a simple but efficient biotechnological tool for recycling organic wastes to produce better end product with the help of some specific group of decomposing bacteria. Studies were carried out to screen the soil borne bacteria from decomposing vegetables and fruits. The collected samples were subjected to Total microbial count, Standard plate count, Coli form count and Biochemical tests to identify the bacteria present in it. Bacillus sp. and Pseudomonas sp. dominantly found in the sample were identified and confirmed by their morphological and biochemical characters. The isolates were sub cultured and involved in composting process. The physical and biochemical activities occurred during 50 days of composting period were analyzed. The moisture content, $\mathrm{pH}$, Electrical conductivity, energy sources such as Carbon, Nitrogen, Phosphorous, Potassium content and C:N of the compost prepared using bacterial cultures were compared with that of the control. An experimental study was also conducted to find out the effect of compost on germination, root length and shoot length of green gram plant. Towards the end the positive outcome substantiated that microbial biotechnology is a powerful tool for the decomposition of kitchen waste into a value added material.
\end{abstract}

Keywords: Compost, Bacillus spp. and Pseudomonas spp.

\section{Introduction}

Environmental degradation is a major threat confronting the world and the rampant use of chemical fertilizers contributes largely to the deterioration of the environment. It leads to loss of soil fertility due to imbalanced use of fertilizers that has adversely impacted agricultural soil. So, sustainable organic farming practices can reverse the declining trends in the global productivity. On one hand tropical soils are deficient in all necessary plant nutrients and on the other hand large quantities of such nutrients contained in domestic wastes and agricultural by products are wasted. It is estimated that in cities and rural areas of India nearly 70 million ton organic waste is generated annually which is either burned or land filled (Bhinday, 1994).

In nature's laboratory there are numbers of organisms that have the ability to convert organic waste into valuable resources containing plant nutrients and organic matter, which can enrich soil productivity and minimize environmental degradation. Microbial conversion of vegetable waste to biofertilizer is a feasible and potential technology in the future to maintain the natural resources and to reduce the impact on environmental quality. It is a simple biotechnological process of composting, in which certain species of bacteria are used to enhance the process of waste conversion and produce a better end product.

There are several naturally occurring micro organisms that are able to convert organic waste into valuable resources such as plant macro and micro nutrients, and reduce the $\mathrm{C}: \mathrm{N}$ ratio to support soil productivity. These micro organisms are also important to maintain nutrient flows from one system to another and to minimize ecological imbalance ( Novinsak et al., 2008; Umsakul et al., 2010).

Many fruits and vegetables present nearly ideal conditions for the survival and growth of many types of micro organisms. The internal tissues are nutrient rich and have a $\mathrm{pH}$ nearly neutral because the principal storage polymer is starch. During the composting process, various parameters including C:N ratio, composting temperature, $\mathrm{pH}$ of the finished product, moisture content and the presence of potential pathogens such as coli form bacteria are used to assess the quality and stability of the compost (Wu and Ma 2002; Steger et al., 2007; Sanmanee et al., 2011). In the present study, a simple microbiological process, this could provide a solution to the problem of kitchen waste disposal, and for recycling of solid waste into useful manure by the action of decomposing bacteria.

\section{Collection of organic wastes}

\section{Materials and Methods}

Vegetable waste was collected from a waste dispersal yard of vegetable market, Erode District. Discarded vegetables fruits, leaves, peeled off materials etc., were collected in large sized plastic bags and brought to the laboratory. 


\section{Collection of soil samples}

Soil samples were collected from decomposing pit, organic agricultural farm and the area dumped with vegetable market wastes. The soils were collected in sterile polythene zip lock covers and stored in the refrigerator without losing moisture content at $5^{\circ} \mathrm{C}$.

\section{Enumeration of Microbes}

The soil samples were rinsed thoroughly with distilled water and serially diluted up to $10^{-7}$ and further dilution was made depending on bacterial density. The highest dilutions were taken for analyzing the total microbial count by using Nutrient agar medium at $37^{\circ} \mathrm{C}$ for 24 hours. Standard Plate Count (SPC) was carried out by spread plate Technique and Coli form Count (CC) was carried out by pour plate technique.

\section{Isolation of Bacteria}

According to Bergey's Manual of Determinative Bacteriology, the microorganisms were isolated. Morphological and culture characteristics such as abundance of growth, pigmentation, optical characteristics, form, size, margin and elevation of the microbes were studied on Nutrient agar plates.

\section{Identification of Bacteria}

Gram's staining technique was carried out to identify gram positive and gram negative bacteria. Hanging drop technique was applied to find out the motility of bacteria. Biochemical tests like Indole production test, Methyl red test, Voges - proskauer test, Gelatin hydrolysis, Carbohydrate utilization analysis, Catalase test, Oxidase test, Nitrate reduction test, Starch hydrolysis test, Casein hydrolysis test, Carbohydrate fermentation test and Endospore examination were carried out to isolate Bacillus species and Pseudomonas species in the culture. The isolated bacteria were sub cultured and microbial consortium prepared with Bacillus sp. and Pseudomonas sps. were utilized to decompose vegetable waste (Table 1).

\section{Experimental set up}

The experiments were conducted in grow bags. (width 14", Depth 11.5", Height 17") of 30 litre capacity. The waste were chopped and dried for a day. Ten kilogram of the vegetable waste was mixed with pure culture broth of Bacillus sp. and Pseudomonas sp. separately and filled in the grow bags and water was sprayed over it. The control was prepared without the addition of microbial culture. Both control and experimental setups were periodically mixed well. After about 25 to 30 days the volume of bed had dropped substantially and a sweet smelling white mould appear on the biomass. After that it was left undisturbed for 10 to 15 days. At this point the finished compost was collected after 50 days. The sample drawn from control and test were subjected to microbial and physio chemical analysis during different periods of composting. Samples were withdrawn from the $20 \mathrm{~cm}$ depth of pits for every 10days interval up to 50 days. The microbial load was estimated by using serial dilution method.

\section{Physiochemical analysis}

$\mathrm{pH}$ and EC were determined by the method described by ISI Bulletin (1982). The organic carbon was determined by the emprical method followed by Walkely and Black (1934). The total nitrogen ( N\%), total Phosphorus (P\%), Total Potassium ( $\mathrm{K} \%$ ) content of the sample was estimated by Kjeldahl method as per Tandon (1993 ), colorimetric method for phosphorus and flame photometric method for potassium. CN ratio was calculated by dividing the percentage of carbon estimated for the manure sample with the percentage of nitrogen estimated for the same manure sample.

\section{Crop production using vegetable compost}

Approximately 50 seeds of green gram (Cicer arietinum) soaked overnight in sterile distilled water were sown in micro plots containing soil and vegetable compost and water was sprayed regularly without any conventional agricultural practices. The seedlings germinated within 48 to 72 hours and growth of plantlets was observed for 15 days and various growth parameters were analyzed and the results were recorded.

Table 1 : Morphological \& Biochemical profile of the bacterial isolates

\begin{tabular}{|l|l|l|l|}
\hline S.No. & Characteristic/ Test & Bacillus Species & Pseudomonas Species \\
\hline 1. & Shape & Rod & Rod \\
\hline 2. & Gram's staining & + & - \\
\hline 3. & Motility & + & - \\
\hline 4. & Endospore & + & - \\
\hline 5. & Indole test & - & - \\
\hline 6. & Methyl red test & - & - \\
\hline 7. & Voges-proskauer test & - & - \\
\hline 8. & Gelatin hydrolysis & + & - \\
\hline
\end{tabular}


Microbial Conversion of Vegetable Wastes for Bio fertilizer Production

\begin{tabular}{|l|l|l|l|}
\hline 9. & Carbohydrate utilization & + & + \\
\hline 10. & Catalase test & + & + \\
\hline 11. & Oxidase test & + & + \\
\hline 12. & Nitrate reduction test & + & + \\
\hline 13. & Starch hydrolysis test & + & - \\
\hline 14. & Casein hydrolysis test & + & - \\
\hline 15. & Carbohydrate fermentation & + & + \\
\hline
\end{tabular}

Table 2: Physiochemical Analysis of the Compost prepared using Bacillus Sp.

\begin{tabular}{|c|c|c|c|c|c|c|c|c|c|c|c|}
\hline \multirow{3}{*}{ Parameters } & & \multicolumn{10}{|c|}{ Compost sample } \\
\hline & \multirow{2}{*}{$\begin{array}{l}\text { Contro } \\
1 / \text { Test } \\
0 \text { day }\end{array}$} & $\begin{array}{l}\text { Con } \\
\text { trol }\end{array}$ & $\begin{array}{l}\mathrm{Te} \\
\text { st }\end{array}$ & $\begin{array}{l}\text { Cont } \\
\text { rol }\end{array}$ & Test & $\begin{array}{l}\text { Cont } \\
\text { rol }\end{array}$ & $\begin{array}{l}\text { Te } \\
\text { st }\end{array}$ & $\begin{array}{l}\text { Cont } \\
\text { rol }\end{array}$ & Test & $\begin{array}{l}\text { Contro } \\
1\end{array}$ & Test \\
\hline & & \multicolumn{2}{|c|}{10 days } & \multicolumn{2}{|c|}{ 20days } & \multicolumn{2}{|c|}{30 days } & \multicolumn{2}{|c|}{40 days } & \multicolumn{2}{|l|}{50 days } \\
\hline $\begin{array}{l}\text { Moisture } \\
\text { Content \% }\end{array}$ & 50 & 50 & 52 & 54 & 56 & 46 & 49 & 42 & 44 & 41 & 33 \\
\hline $\mathrm{EC}$ & 0.32 & 0.33 & $\begin{array}{l}0.3 \\
7\end{array}$ & 0.34 & $\begin{array}{l}0 . .4 \\
0 \\
\end{array}$ & 0.38 & $\begin{array}{l}0.4 \\
1\end{array}$ & 0.41 & 0.58 & 0.57 & 0.74 \\
\hline $\mathrm{pH}$ & 6.8 & 6.5 & 6.6 & 7.2 & 6.9 & 6.3 & 6.4 & 6.3 & 6.0 & 6.2 & 6.0 \\
\hline Lime Status & Nil & Nil & Nil & Nil & Nil & Nil & Nil & Nil & Nil & Nil & Nil \\
\hline $\begin{array}{l}\text { Organic } \\
\text { Carbon } \%\end{array}$ & 19.76 & $\begin{array}{l}19.5 \\
6 \\
\end{array}$ & $\begin{array}{l}19 . \\
11\end{array}$ & 19.25 & $\begin{array}{l}18.7 \\
5 \\
\end{array}$ & 19.05 & $\begin{array}{l}17 . \\
65\end{array}$ & 18.96 & 16.14 & 17.60 & 15.05 \\
\hline Total N \% & 6.74 & 6.91 & $\begin{array}{l}7.2 \\
3 \\
\end{array}$ & 7.11 & 9.22 & 7.24 & $\begin{array}{l}14 . \\
97\end{array}$ & 9.58 & 17.13 & 11.54 & 21.87 \\
\hline $\mathrm{C}: \mathrm{N}$ & 45.24 & $\begin{array}{l}44.2 \\
7\end{array}$ & $\begin{array}{l}43 . \\
98\end{array}$ & 42.13 & $\begin{array}{l}33.1 \\
5\end{array}$ & 38.56 & $\begin{array}{l}29 . \\
57\end{array}$ & 36.25 & 22.36 & 30.04 & 15.45 \\
\hline $\begin{array}{l}\text { Phosphorou } \\
\text { s \% }\end{array}$ & 3.24 & 3.48 & $\begin{array}{l}4.2 \\
9\end{array}$ & 5.21 & 6.33 & 5.75 & $\begin{array}{l}8.1 \\
1 \\
\end{array}$ & 6.33 & 8.26 & 6.71 & 8.78 \\
\hline $\begin{array}{l}\text { Potassium } \\
\%\end{array}$ & 4.16 & 5.21 & $\begin{array}{l}7.4 \\
5 \\
\end{array}$ & 5.86 & 11.0 & 7.45 & $\begin{array}{l}13 . \\
55\end{array}$ & 7.62 & 14.36 & 9.25 & 16.88 \\
\hline
\end{tabular}

Table 3: Physiochemical Analysis of the Compost prepared using Pseudomonas Sp.

\begin{tabular}{|c|c|c|c|c|c|c|c|c|c|c|c|}
\hline \multirow{3}{*}{ Parameters } & & \multicolumn{10}{|c|}{ Compost sample } \\
\hline & \multirow{2}{*}{$\begin{array}{l}\text { Contro } \\
\text { 1/Test } \\
0 \text { day }\end{array}$} & $\begin{array}{l}\text { Contr } \\
\mathrm{ol}\end{array}$ & Test & $\begin{array}{l}\text { Contro } \\
1\end{array}$ & Test & $\begin{array}{l}\text { Contro } \\
1\end{array}$ & Test & $\begin{array}{l}\text { Contro } \\
1\end{array}$ & Test & $\begin{array}{l}\text { Contro } \\
1\end{array}$ & Test \\
\hline & & \multicolumn{2}{|c|}{10 days } & \multicolumn{2}{|l|}{ 20days } & \multicolumn{2}{|l|}{30 days } & \multicolumn{2}{|l|}{40 days } & \multicolumn{2}{|l|}{50 days } \\
\hline $\begin{array}{l}\text { Moisture } \\
\text { Content } \%\end{array}$ & 58 & 56 & 57 & 50 & 45 & 46 & 39 & 41 & 34 & 39 & 31 \\
\hline $\mathrm{EC}$ & 0.32 & 0.36 & 0.38 & 0.34 & $0 . .42$ & 0.38 & 0.41 & 0.41 & 0.58 & 0.57 & 0.88 \\
\hline $\mathrm{pH}$ & 6.5 & 6.6 & 6.6 & 7.3 & 6.7 & 7.3 & 7.4 & 7.3 & 7.8 & 7.6 & 8.0 \\
\hline Lime Status & Nil & Nil & Nil & Nil & Nil & Nil & Nil & Nil & Nil & Nil & Nil \\
\hline $\begin{array}{l}\text { Organic } \\
\text { Carbon\% }\end{array}$ & 19.42 & 19.00 & 19.19 & 18.65 & $\begin{array}{l}17.8 \\
8\end{array}$ & 19.00 & $\begin{array}{l}17.3 \\
5\end{array}$ & 18.96 & 16.14 & 17.60 & 14.35 \\
\hline Total N \% & 6.12 & 7.08 & 8.20 & 7.19 & 9.20 & 8.28 & $\begin{array}{l}14.9 \\
7\end{array}$ & 9.58 & 11.13 & 13.54 & 23.87 \\
\hline $\mathrm{C}: \mathrm{N}$ & 45.10 & 44.18 & 41.90 & 42.07 & $\begin{array}{l}36.1 \\
5\end{array}$ & 36.56 & $\begin{array}{l}29.5 \\
5\end{array}$ & 36.25 & 22.36 & 30.17 & 17.45 \\
\hline $\begin{array}{l}\text { Phosphorou } \\
\text { s \% }\end{array}$ & 3.23 & 3.98 & 4.35 & 5.25 & 6.05 & 6.15 & 8.11 & 6.33 & 8.29 & 6.77 & 9.78 \\
\hline $\begin{array}{l}\text { Potassium } \\
\%\end{array}$ & 4.18 & 5.10 & 6.45 & 6.80 & 11.0 & 7.40 & $\begin{array}{l}13.5 \\
5\end{array}$ & 8.69 & 14.36 & 9.45 & 15.54 \\
\hline
\end{tabular}

Table 4: Effect of compost on the growth of green gram (Cicer arietinum)

\begin{tabular}{|l|l|l|l|l|l|l|l|l|l|l|}
\hline \multirow{2}{*}{ Parameters } & \multicolumn{3}{|l|}{ Control } & \multicolumn{3}{l|}{ Bacillus spp. Compost } & \multicolumn{2}{l|}{$\begin{array}{l}\text { Pseudomonas } \\
\text { Compost }\end{array}$} \\
\cline { 2 - 11 } & $5^{\text {th }}$ day & $\begin{array}{l}10^{\text {th }} \\
\text { day }\end{array}$ & $\begin{array}{l}15^{\text {th }} \\
\text { day }\end{array}$ & $\begin{array}{l}5 \\
\text { day }\end{array}$ & $10^{\text {th }}$ day & $\begin{array}{l}15^{\text {th }} \\
\text { day }\end{array}$ & $\begin{array}{l}5 \\
\text { day }\end{array}$ & $\begin{array}{l}10 \\
\text { day }\end{array}$ & $\begin{array}{l}15^{\text {th }} \\
\text { day }\end{array}$ \\
\hline Shoot length & 1.1 & 1.8 & 3.4 & 2.3 & 5.3 & 6.1 & 3.7 & 4.1 & 7.3 \\
\hline Root length & 1.3 & 2.3 & 4.1 & 3.0 & 3.5 & 5.0 & 4.7 & 4.9 & 5.6 \\
\hline
\end{tabular}




\section{Results and Discussion}

The physical and chemical parameters were determined periodically. The time taken for the degradation process to form compost was 50 days. In the case of vegetable wastes, the decomposition process was started after the application of the inoculum which was visualized clearly after the 15 days of application by appearance of microbial growth. A sharp decrease in volume and colour change, development of pleasant odour, changes in texture and less water activity was seen. The same observation was occurring rapidly in the successive days also. The complete decomposition was clearly observed on the 50th day, which was clearly identified by sharp decrease in volume (3/4th of the volume) complete decolourization, complete absence of water content and complete conversation of finely ground powder which reveal the decomposition of vegetable wastes into fine powder. The temperature of the compost was increasing gradually in the first week and attained maximum on $15^{\text {th }}$ day and started decreasing after wards. After a month it reached the normal. pH

The $\mathrm{pH}$ of the compost was lower in all the experimental set ups than their initial values (Tables 2and 3). The decrease in $\mathrm{pH}$ value at the final stage of compost formation may be due to the production of $\mathrm{CO}_{2}$ and organic acids by microbial metabolism during decomposition of different substrates in the vegetable waste (Albanell et al., 1998 ; Chan and Griffiths, 1988).

\section{Electrical conductivity $($ EC)}

Gradual increase in EC was recorded in all the experimental setups (Tables 2and 3). This may be attributed due to freely available ions and minerals that are generated during decomposition process.

\section{Total organic carbon (TOC)}

Total organic carbon decreased more significantly with time in experimental setups compared to control at the final stage of compost formation (Tables 2and 3). The final reduction in TOC values was possibly due to the rapid respiration rate that leads to the loss TOC in terms of $\mathrm{CO}_{2}$ or was probably due to the fact that the organic carbon was utilized by the microbes and resulted in reduction in TOC.

\section{Total nitrogen (TKN)}

Total nitrogen content of the composed increased significantly with time in the presence of decomposing thermophilic bacteria. This could be probably due to mineralization of organic matter (Tables 2and 3). Decrease in pH may be an important factor in Nitrogen retention as this element is lost as volatile ammonia at highest pH (Gautham et al., 2010). According to Viel et al., (1987) loss in organic carbon might be responsible for nitrogen enhancement. Pseudomonas bacteria also have great impact on nitrogen transformation in manure, by enhancing nitrogen mineralization, so that mineral nitrogen may be retained in the nitrate form (Atiyeh et al., 2000). However in general the final nitrogen content of compost is dependent on the initial nitrogen present in the waste and the extent of decomposition (Gaur and Singh 1995). In the present study, the vegetable wastes were effectively decomposed by the applied microbes. It is due to increased microbial activity continues in the casts and results in an increased rate of mineralization of organic nitrogen and consequently further increase in concentration of $\mathrm{NO}_{4}+($ Sekaran, 2007).

\section{Total phosphorus (TP)}

The total phosphorus increased significantly in the experimental setup than the control (Tables2and 3). Increase in TP during compost formation by bacterial action is probably due to mineralization and mobilization of phosphorus and enzymatic activity of bacteria (Edwards and Lofty, 1972).

\section{Total potassium (TK)}

Results revealed that the total potassium also increased at the final stage of composting. These increased levels of TK at the final product than the initial feed substrate indicate that the microbial flora also influences the level of available potassium (Tables 1 and 2). Acid production by the micro organisms seems to be prime mechanism for solubilizing the insoluble potassium.

\section{Carbon- Nitrogen ratio $(C: N)$}

The $\mathrm{C} \mathrm{N}$ ratio has decreased drastically during compost formation. The $\mathrm{CN}$ ratio traditionally considered as a parameter to determine the degree of maturity of compost. $\mathrm{C} N$ ratio below 20 is an indication of acceptable maturity. While a ratio of 15 or below being preferable. (Marais and Queda, 2003 ). Referring to this study, the $\mathrm{CN}$ ratio of the compost prepared using microbial inoculum is also within the acceptable limit (Tables 1 and 2) 


\section{Plant growth parameters}

The germination efficiency of green gram ( Cicer arietinum) seeds was shown to be higher in the microbial inoculum added compost. Plants stem length, root length was also found to increase in experimental compost than in the control. The maximum plant height was observed in the microbial culture added vegetable waste compost (Table 4). The increase in growth parameters might be due to availability of free amino acids, micronutrients and important macronutrients. The microorganisms of the compost were needed energy source like Carbon, Nitrogen, Potassium, and Minor elements were essential to make enzyme and their activity. Composting is a good organic method of enriching the soil. Compost can be easily prepared in a short span of time in the pots with garden and kitchen refuse using mesophilic microbial consortium prepared from the soil borne bacteria. The decomposing bacteria help in converting unavailable nutrients like nitrogen to ammonia and nitrates making it usable for the growth of lush foliage. More availability of phosphorus helps in the development of strong roots and potassium protects plants from disease attack thereby increases the total yield. The microorganism of the compost needed energy source like Carbon, Nitrogen, Potassium and minor elements were also needed by them to make enzyme and their activity.

The present technique is the easiest method to convert the waste into a byproduct which can be utilized as an eco friendly soil fertilizer. The kitchen waste provided a better environment for the decomposing microbes to grow and produce a higher quality of bio fertilizer. The organic matter helps in soil management for sustainable cultivation of any crop. The adaptation of the new technology leads to detoxification of our landfills, decontamination of our environment and promotes highly sustainable agricultural and organic waste treatment. It is not only environment friendly, but also protects the environment.

\section{Acknowledgement}

The author sincerely thank University Grants Commission (UGC) for their financial assistance in doing the Minor Research project successfully.

\section{References}

[1]. Albanell, E., Plaixats, J., Cabrero, T., 1988. Chemical change during vermicomposting (Eisenia foetida) of sheep manure mixed with cotton industrial waste. Biol. Fert. Soils 6 (3), 266-269

[2]. Atiyeh, R.M., Dominguez, J., Subler, S., Edwards, C.A., 2000. Changes in biochemical properties of cow manure during processing by earthworms (Eisenia andrei Bouche) and the effects on seedling growth. Pedobiologia 44, 709-724

[3]. Bhiday MR. 1994. Earthworms in agriculture. Indian Farming 43(12):31-34.

[4]. Chan, P.L.S., Griffiths, D.A., 1988. Chemical composting of pretreated pig manure. Biol. Waste 24, 57-69.

[5]. Edwards, C.A., Lofty, J.R., 1972. Biology of Earthworms. Chapman and Hall, London morais ,F.M.C., Queda, C.A.C., 2003. Study of storage influence on evalution of stability and maturity properties of MSW compost. In: Advances for a sustainable society part II, Perth (Austrlia)

[6]. Gaur, A.C., Singh, G., 1995. Recycling of rural and urban waste through conventional and vermicomposting. In: Tondon, H.L.S. (Ed.), Recycling of Crop, Animal, Human and Industrial Waste in Agriculture. Fertilizer Development and Consultation Organization, New Delhi, pp. 31-49.

[7]. Gautam SP, Bundela PS, Pandey AK, Awasthi MK, Sarsaiya S. Composting of municipal solid waste of Jabalpur city. Global J Environ Res. 2010;4:43-46.

[8]. Novinsak A, Surette C, Allain C, Filion M. Application of molecular technologies to monitor the microbial content of biosolids and composted biosolids. Water Sci Technol. 2008;57:471-477. doi: 10.2166/wst.2008.019.

[9]. Sanmanee N, Panishkan K, Obsuwan K, Dharmvanij S. Study of compost maturity during humification process using UVspectroscopy. World Acad Sci Eng Technol. 2011;80:403-405

[10]. Sekaran,Venkatachalapathy,RajagopalKrishnan,Karuthapandian,Shanmugiah (2007)Cost-effective activated sludge process using Effective microorganisms(EM)Envrironmental Health7:71-83.

[11]. Steger K, Sjogren AM, Jarvis A, Jansson JK, Sundh I. Development of compost maturity and Actinobacteria populations during full-scale composting of organic household waste. J Appl Microbiol. 2007;103:487-498. doi: 10.1111/j.1365-2672.2006.03271

[12]. Umsakul K, Dissara Y, Srimuang N. Chemical physical and microbiological changes during composting of the water hyacinth. Pak J Biol Sci. 2010;13:985-992. doi: 10.3923/pjbs.2010.985.992.

[13]. Viel, M., Sayag, D., Andre, L., 1987. Optimization of agricultural, industrial waste management through invessel composting. In: de Bertoldi, M. (Ed.), Compost: Production, Quality and Use. Elsevier Appl. Sci., Essex, pp. 230-237.

[14]. Wu L, Ma LQ. Relationship between compost stability and extractable organic carbon. J Environ Qual. 2002;31:1323-1328. doi: $10.2134 /$ jeq2002.1323 